\title{
KEMAMPUAN BACA MAHASISWA PADA BUKU TEKS
}

\author{
Prijana dan Asep Saeful Rohman \\ Program Studi Ilmu Perpustakaan Fakultas Ilmu Komunikasi Universitas Padjadjaran \\ E-mail: prijanafikom@gmail.com ; asep.saefulr@gmail.com
}

\begin{abstract}
ABSTRAK. Tujuan dalam penelitian ini adalahuntuk mengetahui dan menjelaskan kemampuan baca mahasiswa setelah diberi perlakuan membaca dengan metode baca good reading. Metode penelitian: eksperimen, yakni unit eksperimen satu( $\left.\mathrm{N}^{1}=189\right)$, unit eksperimen dua $\left(\mathrm{N}^{2}=68\right)$, unit eksperimen $3\left(\mathrm{~N}^{3}=129\right)$, unit eksperimen $4\left(\mathrm{~N}^{4}=57\right)$, unit eksperimen $5\left(\mathrm{~N}^{5}=61\right)$.Hasil penelitian: strata IPK mahasiswa memiliki hubungan non-signifikan dengan metode baca good reading. Strata IPK memiliki hubungan non-signifikan dengan waktu baca.Faktor keterampilan baca dan keterlatihan diduga memiliki keterkaitan dengan waktu baca.Semakin terampil dan terlatih untuk membaca, semakin singkat waktu bacanya. Kesimpulan: Mereka yang memiliki IPK tinggi lebih terampil baca dibandingkan dengan mereka yang memiliki IPK lebih rendah.
\end{abstract}

Kata kunci: Kemampuan baca, good reading, Buku Teks, Ilmu Pengetahuan, Keterampilan

ABSTRACT. The purpose of this research is to describe and explain the reading skills of students after reading the treatment given by the method of reading good reading. Methods: experiment, the experiment unit one $(\mathrm{N} 1=189)$, the experiment $2(\mathrm{~N} 2=68)$, the unit experiment $3(\mathrm{~N} 3=129)$, experiment $4(\mathrm{~N} 4=57)$, the experiment $5(\mathrm{~N} 5=61)$, Result: The strata GPA student has a non-significant relationship with the method of good reading. Strata GPA have a non-significant relationship with the reading time. Factors reading skills and suspected of having links with the reading time. The more skilled and trained to read, the shorter the time reading. Conclusion: Those who have a high GPA read more skilled than those who have a lower GPA.

Key words: Ability to read, good reading, Textbook, Science, Skills of read

\section{PENDAHULUAN}

Pada awal tahun 1940-an buku dengan judul How to Read a Bookkarya Mortimer J. Adler \& Charles Van Doren menggemparkan Eropa, media televisi dan radio turut mempopulerkannya. Mereka memandang bahwa gagasan dalam buku tersebut mengantarkan masyarakat Eropa menjadi literate. Respon positif menyebar dimana-mana dengan cepat dan serempak, sampai merasa perlu menterjemahkan buku: How to read a bookke dalam lima bahasa, yakni Perancis, Swedia, Jerman, Spanyol, dan Itali. Pada tahun 1972 buku tersebut dicetak dalam edisi Amerika, dan juga berdampak positif pada masyarakat Amerika. Gagasan Adler and Doren ini juga menginspirasi para cendekiawan Amerika, diantaranya Frank Hatt (1976) dalam karya bukunya The reading process yang secara eksplisit mencoba memahami apa itu membaca dan who is the reader? Frank Hatt mencoba untuk memahami dan mengatakan bahwa This reader, in existential reading situation, is a person who is literate, yang selanjutnya ia tegaskan lagi bahwa the reader is a literate person.

Di Indonesia gagasan literate baru terdengar samar-samar sekitar tahun 2010-an, walau gagasan masyarakat membaca sudah muncul pada tahun 1990an. Sebelum-nya gagasan yang muncul di masyarakat adalah ayo sekolah yang menjadi program andalan pemerintah sampai dengan saat ini. Dibalik gagasan besar Adler and Doren tersebut, mereka memiliki pandangan baru yang selama ini belum semuanya terungkap dengan lebih terang. Adler and Doren (1972) dalam edisi Amerika menegaskan bahwa reading is tools. Gagasan inilah yang menginspirasi Moyle (1973) untuk menciptakan formula baru tentang membaca yang ia sebut dengan good reading. Sehingga semakin jelas bahwa membaca itu memerlukan skilldan dilengkapi dengan tatacara (ordering) membaca yang benar. Gagasan Moyle inilah yang mengantarkan idea untuk melakukan sebuah penelitian eksperimen. Disini gagasan penelitian dilatarbelakangi oleh adanya aktivitas membaca mahasiswa dengan hasil yang berbedabeda. Frank Hatt dalam Sukaesih, 2007 menyebutnya bahwa aktivitas membaca itu sebagai aktivitas artifisial (artificial activity).

Barangkali apa yang kita pahami selama ini bahwa prestasi akademik mahasiswa disebabkan oleh faktor IQ. Disisi yang lain ada yang mengatakan karena faktor belajar (learning). Karena itu disini yang akan menjadi fokus penelitian adalah faktor belajar mahasiswa dengan cara membaca, khususnya akses pada materi bacaan buku teks (access to reading matter) dan beban waktu membaca (time to read), yang oleh Frank Hatt dikatakan sebagai faktor yang membedakan hasil aktivitas artifisial manusia.

Moyle (1973) menyarankan cara membaca buku yang benar melalui metode bacagood reading, yakni sbb: Pertama, cara membaca buku yang benar harus diawali dengan cara membaca dengan cepat (read faster). Disini cara membaca dengan cepat berbeda dengan cara membaca dengan tergesa-gesa. Cara membaca dengan cepat membutuhkan latihan agar memiliki ketrampilan membaca dengan cepat. Kemampuan seseorang inilah yang harus dilatih dengan cara yang benar. Cara membaca dengan cepat juga butuh konsentrasi. Disini 
hal konsentrasi juga butuh latihan. Jadi membaca dengan cepat dan konsentrasi memerlukan latihan. Adler \& Doren (1972) mengatakan bahwa konsentrasi baca yang paling baik ketika seseorang pada posisi duduk, bukan pada posisi berdiri atau tiduran.

Setiap orang akan menetapkan kemampuannya masing-masing untuk membaca dengan cepat yang menurutnya paling nyaman (enjoy read). Kedua, membaca ulang seluruh dari apa yang sudah dibaca (Read More), dengan asumsi sudah mengenal istilahistilah kata dalam materi bacaan. Jika terdapat istilah kata yang belum dikenal, maka penting untuk mengenalinya terlebih dahulu. Selanjutnya baru dilakukan membaca ulang secara keseluruhan dengan membaca cepat (read faster). Barangkali logis bahwa tempo waktu untuk membaca ulang akan lebih cepat. Ketiga, membaca ulang sekali lagi sebagian atau seluruhnya dari apa yang sudah dibaca untuk maksud memahami teks.

\section{METODE PENELITIAN}

Metode Penelitian yang digunakan dalam penelitian ini adalah eksperimen. Earl Babbie (1986) dalam karya bukunya: The Practice of Social Research menyebutkan bahwa metode eksperimen merupakan salah satu bentuk dari metode observasi (the mode of observatio). Gay (1976) sudah menegaskan bahwa metode eksperimen merupakan suatu metode penelitian yang menguji hipotesis, mengenai hubungan sebabakibat, atau yang lebih dikenal dengan kausalitatif. Memang diakui bahwa metode eksperimen merupakan metode yang paling sahih dalam penelitian Ilmuilmu Sosial. Ary, dkk. (1972) bahkan sudah pernah menegaskan bahwa metode eksperimen merupakan metode yang paling tangguh (sophisticated). Ia juga mengurai metode eksperimen kedalam tiga karakteristik sbb: pertama, variabel bebas (independent variable) adalah variabel yang dimanipulasi. Kedua, variabel lain, kecuali variabel terikat adalah konstan. Ketiga, pengaruh manipulasi variabel bebas terhadap variabel terikat dapat diamati dan diukur. Good (1935) sebelumnya juga mencoba memahami metode eksperimen sbb : paling sedikit dapat dilakukan dalam satu kondisi yang dapat dimanipulasikan, sementara kondisi yang lain dianggap konstan. Kemudian pengaruh perbedaan kondisi tersebut dapat diukur. Manipulasi kondisi atau yang dikenal juga dengan variabel ini, merupakan karakteristik yang membedakan penelitian Eksperimen dengan metode penelitian lainnya. Variabel bebas (independent variable) juga dapat diartikan sebagai variabel eksperimen, yang karakteristiknya diyakini dapat menghasilkan perbedaan. Sementara variabel terikat (dependent variable) disebutnya sebagai variabel standar (criterion variable) yang merupakan hasil dari penelitian, perubahan, atau perbedaan hasil dalam kelompok merupakan hasil manipulasi variabel bebas.
Dalam metode eksperimen, setidaknya ada satu hipotesis yang diharapkan memiliki hubungan sebabakibat. Hal yang penting, jika kita melakukan eksperimen sesungguhnya itu kita akan mengkonfirmasikan proses eksperimennya itu sendiri. Suatu eksperimen setidaknya terdiri dari dua kelompok, yakni satu kelompok sebagai kelompok eksperimen, dan saru kelompok sebagai kelompok kontrol. Kelompok eksperimen menerima perlakuan penyelidikan, sementara kelompok kontrol menerima perlakuan yang berbeda, atau metode yang biasa dilakukan sebelumnya. Sebagai peneliti harus menghindari kesalahan, berupa tidak memberikan perlakuan apa-apa kepada kelompok kontrol.

Setelah jangka waktu eksperimen selesai, kita akan mengukur variabel terikat, dengan alat ukur yang telah ditentukan sebelumnya (misal, test evaluasi). Tujuannya disini adalah mengevaluasi apakah ada perbedaan antara kedua kelompok tersebut. Selanjutnya kita akan menilai, apakah perlakuan yang diberikan dapat membuat suatu perbedaan atau tidak.

Barangkali suatu hal yang penting adalah memas-tikan bahwa variabel-variabel lainnya pada awal per-cobaan kedua kelompok diasumsikan adalah sama. Dalam pikiran kita yang ada adalah perbedaan yang terjadi hanya disebabkan oleh perlakuan yang diberikan kepada kelompok eksperimen.

Metode analisis yang digunakan adalah statistika deskriptif yakni analisis koefisien kontingensi C. Untuk uji hipotesis digunakan Rumus sbb:

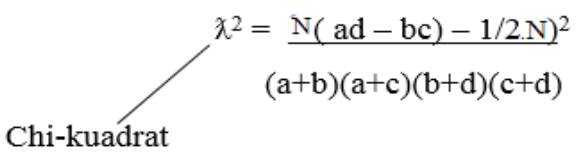

Dilanjutkan dengan mencari Koefisien kontingensi C dengan Rumus:

\section{HASIL DAN PEMBAHASAN}

\section{Hubungan Strata Akademik Mahasiswa Dengan Perilaku Good Reading}

Disini yang dimaksud dengan Perilaku membaca adalah perilaku membaca mahasiswa pada teks Ilmu pengetahuan dengan waktu baca teks 1000 kata dan 2000 kata. Sementara yang dimaksud dengan good reading adalah metode membaca yang memiliki metode step by step yang diawali dengan read faster, kemudian read more, dan diakhiri dengan understanding better. Dalam riset kali ini konsep read faster adalah konsep waktu baca, yakni membaca secara cepat, bukan membaca dengan tergesa-gesa. Demikian juga untuk read more adalah konsep waktu baca, yakni mengulang bacaan pada teks yang sama. Kemudian understanding better adalah juga konsep waktu baca, yakni memahami materi bacaan pada teks yang sama.

Hipotesis: 
Dilanjutkan dengan mencari Koefisien kontingensi C dengan Rumus :

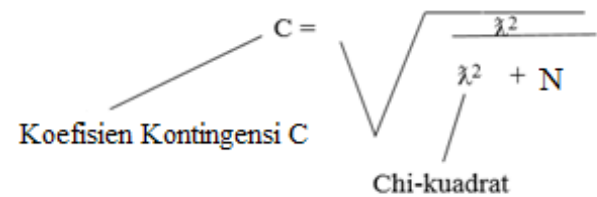

Dilanjutkan dengan mencari harga $\mathrm{C}_{\text {maks }}$ dengan Rumus :

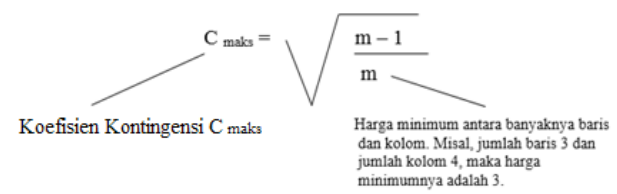

(Sumber : Sudjana, 2005)

\section{Hubungan Strata Akademik Mahasiswa Dengan Perilaku Good Reading}

Disini yang dimaksud dengan Perilaku membaca adalah perilaku membaca mahasiswa pada teks Ilmu pengetahuan dengan waktu baca teks 1000 kata dan 2000 kata. Sementara yang dimaksud dengan good reading adalah metode membaca yang memiliki metode step by step yang diawali dengan read faster, kemudian read more, dan diakhiri dengan understanding better. Dalam riset kali ini konsep read faster adalah konsep waktu baca, yakni membaca secara cepat, bukan membaca dengan tergesa-gesa. Demikian juga untuk read more adalah konsep waktu baca, yakni mengulang bacaan pada teks yang sama. Kemudian understanding better adalah juga konsep waktu baca, yakni memahami materi bacaan pada teks yang sama.

$\mathrm{H}_{0}$ : strata IPK memiliki hubungan non-signifikan dengan waktu baca teks

$\mathrm{H}_{1}$ : strata IPK memiliki hubungan signifikan dengan waktu baca teks

Tabel 1. Hubungan Strata IPK dengan Waktu Baca pada Teks 1000 Kata dan 2000 Kata

\begin{tabular}{|c|c|c|c|}
\hline $\begin{array}{c}\text { Unit } \\
\text { eksperimen }\end{array}$ & Teks 1000 kata & $\begin{array}{l}\text { Teks } 2000 \\
\text { kata }\end{array}$ & TOTAL \\
\hline $\begin{array}{c}\text { IPK } \\
(3,51-4,00)\end{array}$ & 23 & & 58 \\
\hline $\begin{array}{c}\text { IPK } \\
(3,00-3,50)\end{array}$ & 15 & & 52 \\
\hline $\begin{array}{c}\text { IPK } \\
(<3,00)\end{array}$ & 22 & & 79 \\
\hline TOTAL & 60 & 129 & 189 \\
\hline
\end{tabular}

Langkah kerja: Analisis statistik

1. Setelah entry data pada sel-sel diagonal, masukkan data waktu baca mahasiswa untuk masing-masing strata IPK pada teks 1000 kata dan 2000 kata. Disini lamanya waktu baca diambil dengan menggunakan metode indeks, bukan rata-rata waktu baca untuk masing-masing strata IPK.
2. Melalui rumus: $\mathrm{E}_{\mathrm{ij}}=\left(\mathrm{N}_{\mathrm{io}} \times \mathrm{N}_{\mathrm{oj}}\right) / \mathrm{N}$ didapatkan angka-angka hasil hitung untuk dimasukkan ( entry data ) pada masing-masing sel diagonal bawah.

3. Menggunakan Rumus $\chi^{2}$ (Chi-kuadrat) diperoleh hasil hitung ( $\chi^{2}=2,42$ ). Sementara jika $\alpha=0,05$ dan $\mathrm{dk}=(3-1)(2-1)=2$ maka diketahui $\chi^{2}$ tabel adalah 5,99 sehingga diketahui $\chi^{2}$ tabel $>\chi^{2}$ hitung, artinya $\mathrm{H}_{0}$ : diterima ; jika $\mathrm{H}_{0}$ : diterima, maka $\mathrm{H}_{1}$ : ditolak, artinya strata IPK memiliki hubungan nonsignifikan dengan waktu baca mahasiswa.

Sebelum kita membahas, apakah strata IPK memiliki hubungan dengan kemampuan baca mahasiswa, jika diukur dari lamanya waktu baca teks. Disini dalam studi eksperimen disyaratkan untuk membandingkannya dengan kelompok kontrol seperti terlihat pada tabel 2 sbb: Hipotesis:

Tabel 2. Hubungan Strata IPK Mahasiswa dengan Perilaku Reading Habit Teks 1000 Kata dan 2000 Kata

\begin{tabular}{|c|c|c|c|}
\hline $\begin{array}{c}\text { Unit } \\
\text { kontrol }\end{array}$ & $\begin{array}{c}\text { Waktu Baca } \\
\text { Teks } \\
1000 \text { kata }\end{array}$ & $\begin{array}{c}\text { Waktu Baca } \\
\text { Teks } \\
2000 \text { kata }\end{array}$ & TOTAL \\
\hline $\begin{array}{c}\text { IPK } \\
(3,51- \\
4,00)\end{array}$ & & & 22 \\
\hline $\begin{array}{c}\text { IPK } \\
(3,00- \\
3,50)\end{array}$ & & & 29 \\
\hline $\begin{array}{c}\text { Pot. } \\
\text { IPK } \\
(<3,00)\end{array}$ & 5 & 19 & 25 \\
\hline TOTAL & 18 & 58 & 76 \\
\hline
\end{tabular}

$\mathrm{H}_{0}$ : strata IPK memiliki hubungan non-signifikan dengan waktu baca teks

$\mathrm{H}_{1}$ : strata IPK memiliki hubungan signifikan dengan waktu baca teks

Langkah kerja : Analisis statistik

1. Setelah entry data pada sel-sel diagonal, masukkan data waktu baca mahasiswa untuk masing-masing strata IPK pada teks 1000 kata dan 2000 kata. Disini lamanya waktu baca diambil dengan menggunakan metode indeks, bukan rata-rata waktu baca untuk masing-masing strata IPK.

2. Melalui rumus: $\mathrm{E}_{\mathrm{ij}}=\left(\mathrm{N}_{\mathrm{io}} \times \mathrm{N}_{\mathrm{oj}}\right) / \mathrm{N}$ didapatkan angka-angka hasil hitung untuk dimasukkan (entry data) pada masing-masing sel diagonal bawah.

3. Menggunakan Rumus $\chi^{2}$ (Chi-kuadrat) diperoleh hasil hitung $\left(\chi^{2}=0,429\right)$. Sementara jika $\alpha=0,05$ dan $\mathrm{dk}=$ $(3-1)(2-1)=2$ maka diketahui $\chi^{2}$ tabel $=5,99$ artinya bahwa $\chi^{2}{ }_{\text {tabel }}>\chi^{2}{ }_{\text {hitung }}$, artinya bahwa $\mathrm{H}_{0}$ : diterima ; jika $\mathrm{H}_{0}$ : diterima, maka $\mathrm{H}_{1}$ : ditolak, artinya strata IPK memiliki hubungan non-signifikandengan waktu baca mahasiswa.

Disini terlihat bahwa hasil hitung kelompok eksperimen $\left(\lambda^{2}=2,42\right)$ dan hasil hitung kelompok kontrol 
$\left(\lambda^{2}=0,429\right)$, artinya hasil hitung kelompok eksperimen lebih besar dari pada hasil hitung kelompok kontrol. Fakta penelitian menunjukkan adanya perbedaan yang positif antara mahasiswa yang diberi perlakuan dengan yang tidak diberi perlakuan, walau keduanya pada derajat kepercayaan 95\% strata IPK mahasiswa memiliki hubungan non-signifikan dengan waktu baca.Hanya jika pada derajat kepercayaan 50\% pada kelompok eksperimen, strata IPK mahasiswa memiliki hubungan signifakan dengan waktu baca. Jadi artinya peluangnya masih 50\% : 50\% bahwa strata IPK mahasiswa memiliki hubungan signifikan dengan waktu baca.

\section{Hubungan Strata IPK Mahasiswa dengan Perilaku Good Reading}

Kali ini kelompok kontrol secara teknis tidak memungkinkan untuk dilakukan eksperimen, karena sebab tidak memenuhi syarat analisis statistik (analisis $\chi^{2}$ ). Sehingga yang akan dilakukan analisis adalah pada kelompok eksperimen saja. Disini kemampuan baca didekati menurut konsep metode dan waktu baca. Waktu baca juga dicermati melalui metode indeks (bukan melalui cara merata-rata waktu baca). Kemudian metode baca dibagi ke dalam tiga ruang, yakni membaca cepat (read faster), membaca kembali (read more), dan membaca untuk memahami (understanding better). Masing-masing ruang memiliki waktu baca sendiri-sendiri, yang secara berturut-turut akan dilakukan analisis data sbb :

Tabel 3. Hubungan Perilaku Good Reading dengan Strata IPK Mahasiswa, Teks 1000 Kata

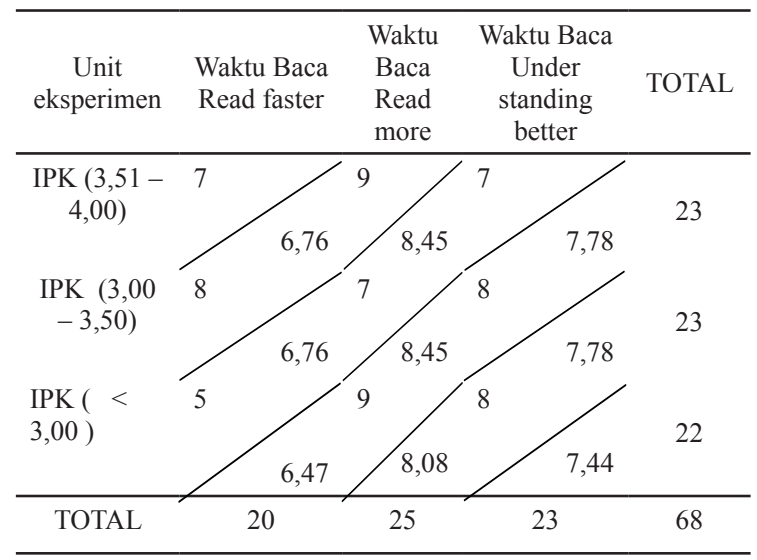

Hipotesis:

$\mathrm{H}_{0}$ : strata IPK memiliki hubungan non-signifikan dengan waktu baca good reading

$\mathrm{H}_{1}$ : strata IPK memiliki hubungan signifikan dengan waktu baca good reading

Langkah kerja : Analisis statistik

1. Setelah entry data pada sel-sel diagonal atas yang ada pada tabel 3. yakni memasukkan data waktu baca mahasiswa untuk masing-masing strata IPK pada teks 1000 kata. Disini lamanya waktu baca diambil dengan menggunakan metode indeks waktu baca, bukan rata-rata waktu baca untuk masing-masing strata IPK yang diambil dari unit eksperimen.
2. Melalui rumus : $\mathrm{E}_{\mathrm{ij}}=\left(\mathrm{N}_{\mathrm{io}} \times \mathrm{N}_{\mathrm{oj}}\right) / \mathrm{N}$ didapatkan angka-angka hasil hitung untuk dimasukkan ( entry data) pada masing-masing sel diagonal bawah.

3. Menggunakan Rumus $\chi^{2}$ (Chi-kuadrat) diperoleh angka hasil hitung $\left(\chi^{2}=1,082\right)$, dengan $\alpha=0,05$ dan $\mathrm{dk}=(3-1)(3-1)=4$ diketahui $\chi^{2}$ tabel adalah 9,49 artinya bahwa $\chi^{2}{ }_{\text {tabel }}>\chi^{2}$ hitung, artinya $\mathrm{H}_{0}$ : diterima; jika $\mathrm{H}_{0}$ : diterima, maka $\mathrm{H}_{1}$ : ditolak artinya strata IPK mahasiswa memiliki hubungan non-signifikan dengan lamanyawaktu baca pada penggunaan metodegood reading.

Fakta peneltian menunjukkan bahwa strata IPK mahasiswa ternyata tidak memiliki hubungan dengan lamanya waktu baca pada read faster, read more, dan understanding better. Mereka mahasiswa memiliki peluangkemampuan baca yang tidak berbeda satu sama lainnya.

\section{Hubungan Perilaku Good Reading Dengan Strata IPK Mahasiswa}

Kali ini kelompok kontrol juga secara teknis tidak memungkinkan untuk dilakukan eksperimen, karena sebab tidak memenuhi syarat analisis statistik (analisis $\chi^{2}$ ). Sehingga yang akan dilakukan analisis adalah pada kelompok eksperimen saja. Disini kemampuan baca didekati menurut konsep metode dan waktu baca. Waktu baca juga dicermati melalui metode indeks, bukan melalui cara merata-rata waktu baca. Kemudian metode baca dibagi ke dalam tiga ruang, yakni membaca cepat (read faster), membaca kembali (read more), dan membaca untuk memahami (understanding better). Masing-masing ruang memiliki waktu baca sendiri-sendiri. Perilaku good reading ini akan dikaitkan dengan strata IPK mahasiswa dengan asumsi bahwa masing-masing strata IPK memiliki kemampuan masing-masing yang berbeda, yang akan dilakukan pada teks 2000 kata, yang secara berturut-turut akan dilakukan analisis data sbb:

Hipotesis:

$\mathrm{H}_{0}$ : strata IPK memiliki hubungan non-signifikan dengan waktu baca good reading

$\mathrm{H}_{1}$ : strata IPK memiliki hubungan signifikan dengan waktu baca good reading

Langkah kerja : Analisis statistik

1. Setelah entry data pada sel-sel diagonal atas yang ada pada table4,yakni memasukkan data waktu baca mahasiswa untuk masing-masing strata IPK pada teks 2000 kata. Disini lamanya waktu baca diambil dengan menggunakan metode indeks waktu baca (bukan rata-rata waktu baca ) untuk masing-masing strata IPK yang diambil dari unit eksperimen.

2. Melalui rumus : $\mathrm{E}_{\mathrm{ij}}=\left(\mathrm{N}_{\mathrm{io}} \times \mathrm{N}_{\mathrm{oj}}\right) / \mathrm{N}$ didapatkan angka-angka hasil hitung untuk dimasukkan ( entry data ) pada masing-masing sel diagonal bawah.

3. Menggunakan Rumus $\chi^{2}$ (Chi-kuadrat) diperoleh angka hasil hitung ( $\left.\chi^{2}=0,694\right)$, dengan $\alpha=0,05$ 
Tabel 4. Hubungan Perilaku Good Reading dengan Strata IPK Pada Teks 2000 Kata

$\begin{array}{cccc}\text { Unit } & \begin{array}{c}\text { Waktu } \\ \text { Baca } \\ \text { Read } \\ \text { eksperimen }\end{array} & \begin{array}{c}\text { Waktu } \\ \text { Baca } \\ \text { Read more }\end{array} & \begin{array}{c}\text { Waktu } \\ \text { Under } \\ \text { standing } \\ \text { better }\end{array} \\ \text { TOTAL } \\ \text { IPK }\end{array}$

dan $\mathrm{dk}=(3-1)(3-1)=4$ diketahui $\chi^{2}$ tabel adalah 9,49 artinya adalah bahwa $\chi^{2}{ }_{\text {tabel }}>\chi^{2}{ }_{\text {hitung }}$, artinya bahwa $\mathrm{H}_{0}$ : diterima ; jika $\mathrm{H}_{0}$ : diterima, maka $\mathrm{H}_{1}$ : ditolak, itu artinya strata IPK mahasiswa tidak memiliki hubungan dengan waktu baca read faster, read more, dan understanding better pad teks 2000 kata.

Jadi analisis teks 2000 kata dengan teks 1000 kata tidak ada perbedaan yang berarti artinya jumlah kata dalam teks tidak mempengaruhi waktu baca mahasiswa walau mereka sesungguhnya memiliki strata IPK yang berbeda.

\section{Hubungan Perilaku Good Reading Dengan IPK Mahasiswa Cumlaude}

Kali ini kelompok kontrol juga secara teknis tidak memungkinkan untuk dilakukan eksperimen, karena sebab tidak memenuhi syarat analisis statistik (analisis $\chi^{2}$ ). Sehingga yang akan dilakukan analisis adalah pada kelompok eksperimen saja. Disini kemampuan baca didekati menurut konsep metode dan waktu baca. Waktu baca juga dicermati melalui metode indeks, bukan melalui cara merata-rata waktu baca. Kemudian metode baca dibagi ke dalam tiga ruang, yakni membaca cepat (read faster), membaca kembali (read more), dan membaca untuk memahami (understanding better). Masing-masing ruang memiliki waktu baca sendirisendiri. Perilaku good reading ini akan dikaitkan dengan strata IPK mahasiswa $(3,51-4,00)$ yang akan dilakukan pada teks 1000 kata dan 2000 kata, yang secara berturutturut akan dilakukan analisis data sbb

Hipotesis:

$\mathrm{H}_{0}$ : waktu baca good reading memiliki hubungan non-signifikan dengan jumlah teks

$\mathrm{H}_{1}$ : waktu baca good reading memiliki hubungan signifikan dengan jumlah teks

Langkah kerja: Analisis statistik

1. Setelah entry data pada sel-sel diagonal atas yang ada pada table5 ,yakni memasukkan data waktu baca good reading pada teks 1000 kata dan 2000 kata.

2. Melalui rumus: $\mathrm{E}_{\mathrm{ij}}=\left(\mathrm{N}_{\mathrm{io}} \times \mathrm{N}_{\mathrm{oj}}\right) / \mathrm{N}$ didapatkan angka- angka hasil hitung untuk dimasukkan (entry data) pada masing-masing sel diagonal bawah.

3. Menggunakan Rumus $\chi^{2}$ (Chi-kuadrat) diperoleh angka hasil hitung $\left(\chi^{2}=0,073\right)$, dengan $\alpha=0,05$ dan $\mathrm{dk}=(3-1)(2-1)=2$ diketahui $\chi^{2}{ }_{\text {tabel }}$ adalah 5,99 ( lihat tabel: distribusi $\left.\chi^{2}\right)$. Disini artinya adalah bahwa $\chi^{2}$ tabel $>\chi^{2}{ }_{\text {hitung }}$, artinya bahwa $\mathrm{H}_{0}$ : diterima ; jika $\mathrm{H}_{0}$ : diterima, maka $\mathrm{H}_{1}$ : ditolakartinya waktu baca good reading memiliki hubungan non-signifikan dengan jumlah teks.

Tabel 5. Hubungan Perilaku Good Reading dengan Teks 1000 Kata Dan 2000 Kata IPK (3,51-4,00)/ Potensi Cumlaude

$\begin{gathered}\text { Unit } \\ \text { eksperimen }\end{gathered}$
$\begin{gathered}\text { Teks } 1000 \\ \text { kata }\end{gathered}$

SIMPULAN

1. Strata IPK mahasiswa memiliki hubungan nonsignifikan dengan metode good reading. Metode baca good reading dapat dilakukan oleh strata IPK lapisan manapun, artinya mereka yang IPK tinggi, sedang, dan rendah memiliki potensi yang sama dalam menggunakan metode baca goodreading.

2. Strata IPK tidak memiliki perbedaan waktu baca ketika membaca dengan melakukan metode baca good reading pada teks 1000 kata dan 2000 kata. Mereka juga tampak enjoy ketika membaca teks 1000 kata sampai dengan 2000 kata. Namun yang menjadi catatan bahwa kelompok eksperimen belum terkondisikan dengan metode baca good reading. Sehingga belum memiliki pola konsisten dalam melaksanakan metode baca.

3. Strata IPK memiliki waktu baca yang relatif sama ketika melaksanakan aktivitas membaca dengan metode baca good reading. Walau tampak bahwa mereka yang memiliki IPK tinggi cenderung lebih cepat dibandingkan dengan mereka yang memiliki IPK lebih rendah. Semakin tinggi IPK, semakin tampak lebih cepat waktu bacanya. Namun melalui uji statistik tidak menunjukkan adanya perbedaan signifikan antara waktu baca IPK tinggi dengan IPK yang lebih rendah. Jika demikian realitanya, maka persoalannya bukan terletak pada tinggi rendahnya IPK yang menentukan waktu baca mereka. Namun yang menentukan waktu baca lebih disebabkan oleh faktor ketrampilan dan keterlatihan. Semakin 
terampil membaca, semakin singkat waktu bacanya. Disini barangkali dapat dibangun asumsi bahwa mereka yang memiliki IPK yang tinggi lebih terampil membacanya dibandingkan dengan mereka yang memiliki IPK lebih rendah.

\section{DAFTAR PUSTAKA}

Adler, Mortimer J. \& Doren, Charles Van. 1972. How to read abook. Amerika: edisi
Babbie, E. 1986. The practice of social research. California: fourth edition, Wadsworth Publishing Co.

Hatt, Frank 1986. The reading process, a framwork for analysis and description. London: Clive Bingley.

Sudjana 2005. Metoda statistika. Bandung: Transito.

Sukaesih 2007. Kemampuan Membaca Dalam Konteks Information Literacy. Bandung: Makalah seminar di Universitas Padjadjaran. 